\title{
Sources of resistance to early blight, Alternaria solani, and transfer to tomato, Lycopersicon esculentum'
}

\author{
Franklin W. Mortin and Paul Hepperly ${ }^{2}$
}

\begin{abstract}
Tomato entries reported as early blight resistant were collected and evaluated under severe early blight infection in the warm rainy summer months of 1982-1985 in Mayagüez, Puerto Rico to identify sources with useful resistance in Puerto Rico. Of the common tomato lines, 84B 510-4 was the closest in resistance to the best wild tomato species, which are less susceptible to early blight than common tomatoes. Useful field resistance was found in the minerity of cases, but one or more entries of $L$. esculentum $\mathrm{f}$. cerasiforme, $L$. pimpinellifolium, $L$. esculentum $\times L$. pimpinellifolium, and $L$. hirsufum var. typicum showed useful early blight resistance. Lowest disease ratings were found in varieties of $L$. hirsurum, which also showed the lowest yield. Better fruiting was found in L pimpinellifolium although resistance levels were slightly less. Crosses of $\boldsymbol{L}$. pimpinellifolium and $L$. hirsufum with useful early blight resistance to susceptible $L$. esculentum were followed in $F_{1}, F_{2}$, and $F_{3}$ generations. Resistance appeared partially dominant from $F_{1}$ disease ratings, and segregation in $F_{2}$ suggested that many modifying genes both dominant and recessive were probably involved in conditioning early blight resisfance. Generally, common tomatoes appear much more susceptible to early blight than wild species. To enlarge the pool of early blight resistence genes, $F_{2}$ selection and progressive back crosses are suggested. Susceptible tomatoes were defoliated by early blight within one month after first flower during the warm rainy months; whereas, entries with useful resistance defoliated from 6 weeks to 2 months after the same stage.
\end{abstract}

\section{INTRODUCTION}

A susceptible host, a well distributed and adapted pathogen, and an environment conducive to disease are the major ingredients for severe epidemics on crop plants. In the warm humid tropics, tomato production is severely limited by diseases. Yang (10) cited 35 fungal and bacterial diseases affecting tropical tomato production. Tomato production has been most difficult in the warm rainy season occurring in summer and fall in Puerto Rico. Not only are warm temperatures harmful to fruit set, but severe early blight consistently causes early defoliation. For successful year-round tomato production a combination of blight resistance and heat tolerance will be essential.

'Manuseript submitted to Editorinl Board May 29, 1986.

${ }^{2}$ Tropical Agriculture Research Station, United States Department of Agrieulture, Agrieultural Research Service, Box 70, Mayagüez, Puerto Rico 00709. 
Early blight is a fungal disease caused by Alternaria solani (Ell. \& Martin). The foliar phase is the most common and destructive one of the diseases. Characteristically, brown necrotic lesions show dark concentric rings associated with periodic development of the fungus. Necrotic patches are surrounded by chlorotic halos caused by fungal toxin production (7). Leaf necrosis and chlorosis lead to premature death of leaves and reduced crop yield and quality. Besides foliar symptoms, collar rot (stem canker) and fruit rots have been attributed to $A$, solani.

Although Reynard and Andrus (8) found resistance to collar rot, no tomatoes currently used in the tropics have adequate early blight resistance. Fungicides are generally used for disease control, greatly increasing production costs and environmental hazards. There are numerous reports of early blight resistance in temperate areas, many of which have never been verified especially under a severe tropical environment. Clark et al. (4) have summarized recent reports of early blight resistance in tomatoes.

Working on foliar resistance to early blight Walter (9) reported that two or more recessive genes control the disease. Barksdale (1) developed techniques for stimulating in vitro conidia formation and inoculating field plants. Lines of processing tomatoes with improved early blight resistance have been developed by Barksdale and Stoner (2) by means of $\mathrm{F}_{2}$ selection after artificial inoeulation of $A$. solani. A wild green fruited tomato, Lycopersicon hirsutum (PI 126445), was used as an early blight resistance source in the Piedmont area of North Carolina (5). Resistance to early blight with this source has decreased under progressive backcrossing; thus both minor and major genes seem to condition early blight resistance.

The metabolic processes which condition resistance to early blight are less understood than the nature of gene action involved in the same process. Zhuchenko et al. (11) found tomatine, a common tomato glycoalkaloid, highly associated with $A$. soloni resistance. Total tannins and phenols were suggested as possible resistance components by Bhatia et al. (3).

Considering the importance of early blight in Puerto Rico, and the lack of verification of many sources reported for early blight resistance, we initiated evaluation of the usefulness of reported sources of resistance under our warm humid summers.

\section{MATERIALS AND METHODS}

All of the Lycopersicon eseulentum, L. pimpinellifolium, and L. hivsutum accessions as well as numerous hybrids and doubtful accessions listed in the compendium of Clark et al. (4) and suggested to be resistant to Alternaria were requested, and most were obtained from the North Central Plant Introduction Station together with seeds of other species. 
Lines segregating for resistance to Alternaria were obtained from Gardner, Barksdale, and Stoner. Cultivars believed to be resistant to collar rot (Manalucie, Floradel, Flora-Dade and Walter) brought the number of accessions to 192 (table 1).

Twenty five plants of each accession were grown in the field at Mayagüez, Puerto Rico, in the summers of 1982-1985. During this season, night temperatures are warm $\left(25^{\circ} \mathrm{C}\right.$ ), the days hotter (up to $32^{\circ} \mathrm{C}$ ), with high humidity and frequent afternoon showers. The plants were established in individual peat pots in late May or early June, transplanted to rows in the field about 5 weeks later, fertilized at the rate of $600 \mathrm{~kg} / \mathrm{ha}$ with 10-10-5 NPK, and irrigated as necessary. Summer rains were highly irregular until August, when they were frequent and intense.

Each year the plants were inspected 3 to 5 times at approximately 2 week intervals and were rated for early blight on the basis of a 0 to 9 scale where, 0 represented no visible symptoms of Altermaria and 9 represented complete defoliation. The infection begins in the lower leaves, and in susceptible hosts is rapidly transmitted through all parts of the plant. In 1983 the young plants at flowering were inoculated with spores of locally collected Alternaria, and in 1984 and 1985 a selected line, Flora-Dade, was planted at the front of each varietal plot to serve as a disease spreader. Each year selections of the most Alternaria free plants were crossed to one or more of three cultivars used as recurrent parents, Flora-Dade, Calypso, or Kewalo. $\mathrm{F}_{1}$ hybrids were often self pollinated in field or greenhouse to obtain $\mathrm{F}_{2}$ seed. When crosses failed, as was common during the hot humid summer, open-pollinated fruits were collected to preserve the most resistant lines.

\section{RESULTS}

The course of the disease was very much the same during each year, and can be illustrated by the records of 1985: August 1, trace infections noted; August 16, Flora-Dade and other susceptible lines with up to 9 infected leaves, resistant lines with 5 or fewer; September 5 , susceptible lines with $50-100 \%$ defoliation, resistant lines with less than $50 \%$ defoliation; September 16, susceptible lines $100 \%$ defoliated, resistant lines 50 100 percent defoliated.

Evaluation was difficult because of great differences in the morphology and maturity of the lines, other defoliating diseases (Buckeye stem canker, Phytophthora parasitica, and leaf mold, Fulvia fulvum syn. Cladosporium fulvum), tangling of the vines of indeterminate types, and regrowth of susceptible indeterminate plants during periodic dry spells. Furthermore, Flora-Dade itself was somewhat resistant and may not be an ideal spreader, except that it still lives and spreads spores when more susceptible lines are already defoliated. The comparison of individual plants in segregating lines was very difficult. Nevertheless, evaluation 
of lines over three to four different dates, and, to a lesser extent, of individual plants in segregating families helped to clarify the resistance status of lines and individual plants.

Table 1 gives the classification of all lines tested and their relative susceptibilities. The vast majority (144) of the lines, identified by PI number or our local numbers, were susceptible or highly susceptible to A. solani and are not identified further here (6). Only one line, cultivar Manalucie, was found partially (lightly) resistant. Six $L$. esculentum f. cerasiforme were lightly resistant and one was usefully resistant. Eleven L. pimpinellifolium lines were lightly resistant and six were highly resistant. Six lines of suspected hybrids of $L$. esculentum $\times L$. pimpinellifolium were lightly resistant. Of only eight $L$. hirsutum f. typicum lines, seven were highly resistant. Furthermore, this resistance appeared to be stronger than any other resistance found in this study. Table 2 gives lines classified as partially resistant or highly resistant.

Of the breeding lines of Gardner and Barksdale and Stoner, in 1982 only one appeared lightly resistant and another highly resistant. In 1985

TABLE 1.-Relative susceptibility of Lycopersicon lines to early blight (Alternaria solani) in Mayagüez, Puerto Rico

\begin{tabular}{|c|c|c|c|c|c|}
\hline \multirow[b]{2}{*}{ Lines } & \multirow[b]{2}{*}{$\begin{array}{l}\text { Number of } \\
\text { lines tested }\end{array}$} & \multicolumn{4}{|c|}{ Number of lines found } \\
\hline & & $\begin{array}{l}\text { Highly } \\
\text { susceptible }\end{array}$ & Susceptible & $\begin{array}{l}\text { Light } \\
\text { resistance }\end{array}$ & $\begin{array}{c}\text { Useful } \\
\text { resistance }\end{array}$ \\
\hline $\begin{array}{l}\text { L. esculentum } \\
\text { Cultivars and primitive } \\
\text { varieties }\end{array}$ & 69 & 58 & 10 & 1 & 0 \\
\hline $\begin{array}{l}\text { Breeding lines for } \\
\text { resistance, Gardner; } \\
\text { Barksdale and Stoner }\end{array}$ & 22 & 14 & 6 & 1 & 1 \\
\hline Derivatives of above lines & 4 & 1 & 1 & 2 & 0 \\
\hline $\begin{array}{l}\text { Barksdale's advanced } \\
\text { lines (1985 only) }\end{array}$ & 10 & 2 & 0 & 8 & 1 \\
\hline L. eseulentum $\mathrm{f}$, cerasiforme & 22 & 6 & 9 & 6 & 1 \\
\hline L. pimpinellifoliam & 25 & 6 & 2 & 11 & 6 \\
\hline Suspected hybrids & 27 & 9 & 12 & 6 & 0 \\
\hline $\begin{array}{l}\text { L. esculentum } \mathrm{x} L \text {. } \\
\text { pimpinellifolium }\end{array}$ & 4 & 0 & 3 & 0 & 1 \\
\hline L. hiosutum var. glabratum & 1 & 0 & 1 & 0 & 0 \\
\hline L. hirsutum var. typicum & 8 & 0 & 0 & 1 & 7 \\
\hline Totals & $\overrightarrow{192}$ & $\overline{96}$ & $\overline{49}$ & $\overline{31}$ & $\overline{16}$ \\
\hline
\end{tabular}

I These 4 categories of susceptibility are based on pragmatic judgement of differences found at the various times each plant was examined. Because each plant was scored several times as disease progressed, the pragmatic score cannot be directly compared to the 0-9 ratings made only for each observation. 
TABLE 2.-Lycopersicon lines classified as light resistance (LR) or useful resistant (UR) to early blight (Altemaria solani)

\begin{tabular}{|c|c|c|c|}
\hline $\begin{array}{c}\text { PI or } \\
\text { other number }\end{array}$ & $\begin{array}{c}\text { Disease } \\
\text { reaction }^{1}\end{array}$ & Nature of line & Subsequent follow up \\
\hline $\begin{array}{l}\text { TARS-T-1 } \\
\text { (Manalucie) }\end{array}$ & LR & $\begin{array}{l}\text { Established cultivar resistant } \\
\text { to collar rot }\end{array}$ & None \\
\hline TARST-148 & UR & Stoner's 81B22 & Backcrossed to Flora-Dade \\
\hline TARS-T-153 & $\mathrm{LR}$ & Stoner's 81B35 & Backcrossed to Flora-Dacte \\
\hline TARS-T-47 & $L R$ & $\begin{array}{l}\mathrm{F}_{1} \text { with Flora-Dade and } \\
\text { Stoner's } 81 \mathrm{~B} 22\end{array}$ & Further backerossing \\
\hline TARS-T- 48 & $\mathrm{LR}$ & $\begin{array}{l}\mathrm{F}_{1} \text { With Flora-Dade and } \\
\text { Stoner's } 81 B 35\end{array}$ & Further backcrossing \\
\hline 100697 & $\mathrm{LR}$ & L. cerasiforme & None \\
\hline 124163 & LR & $"$ & $"$ \\
\hline 126942 & $\mathrm{LR}$ & " & $"$ \\
\hline 127817 & LR & $"$ & $"$ \\
\hline 129041 & LR & $n$ & $n$ \\
\hline 195779 & $\mathrm{LR}$ & $"$ & $"$ \\
\hline 406758 & UR & $n$ & " \\
\hline 127805 & LR & L. pimpinellifolium & $"$ \\
\hline 133542 & LR & " & $"$ \\
\hline 143527 & LR & $"$ & $"$ \\
\hline 212408 & UR & $"$ & $"$ \\
\hline 251320 & UR & $*$ & $"$ \\
\hline 313943 & LR & $"$ & $"$ \\
\hline 344102 & LR & $"$ & $"$ \\
\hline 344103 & LR & $"$ & $"$ \\
\hline 365912 & UR & $"$ & Crossed to Calypso \\
\hline 365917 & $\mathrm{LR}$ & $"$ & None \\
\hline 365928 & UR & $"$ & Crossed to Calypso \\
\hline 379058 & LR & " & None \\
\hline 390519 & UR & $"$ & Crossed to Calypso \\
\hline 390692 & LR & $"$ & None \\
\hline 303662 & UR & $"$ & $"$ \\
\hline 313943 & LR & $"$ & $"$ \\
\hline 112835 & LR & $\begin{array}{l}\text { Suspected hybrid, } \\
\text { L. esculentum } \\
\text { x L. pimpinellifolizm }\end{array}$ & " \\
\hline 118405 & LR & $"$ & $"$ \\
\hline 118407 & LR & $"$ & " \\
\hline 118784 & LR & $"$ & $"$ \\
\hline 205014 & LR & $n$ & " \\
\hline 309815 & LR & $"$ & $"$ \\
\hline 390513 & UR & L. hirsutum & Crossed to $L$. esculentum \\
\hline 390514 & UR & s & " \\
\hline 390516 & UR & $"$ & $"$ \\
\hline 390658 & UR & $"$ & $"$ \\
\hline 390659 & LR & $"$ & $"$ \\
\hline 390660 & UR & $"$ & $"$ \\
\hline 390662 & UR & $"$ & $"$ \\
\hline 390663 & UR & $"$ & $"$ \\
\hline
\end{tabular}

' UR $=$ Useftul resistance and LR = light resistance (see note, table 1). 
only three of the more advanced lines of Barksdale appeared lightly resistant, and one usefully resistant.

A very large number of crosses were made with the standard $L$. esculentum cultivars. The majority of these crosses failed, but later it was possible to repeat some of the crosses and some $F_{1}$ hybrids were obtained.

\section{Resistance in hybrids with $\mathrm{L}$. hirsutum}

L. hirsutum f. glabratum is usually not sufficiently resistant to be used as a source. The $F_{1}$ 's with $f$. typicum were partially or highly resistant to $A$. solani. The plants are large and vigorous, variable in flowering and fruiting, and never carried a normal fruit load, which in itself might give a false indication of resistance. Parent lines differed in resistance carried to the $\mathrm{F}_{1}$ (table 3 ).

If resistance is controlled chiefly by dominant genes, it should appear also in the first backcross to the recurrent $L$. esculentum parent. The levels of resistance found in some $\mathrm{BC}_{1}$ and $\mathrm{BC}_{2}$ hybrids reached the useful (UR) level in several cases. This was also true in $\mathrm{F}_{2}$ from $\mathrm{BC}_{1}$ hybrids (table 4).

Ususally one can select from $\mathbf{F}_{2}$ generations for the most resistant plants in order to capture recessive as well as dominant genes for resistance. In practice, this proved difficult. $F_{2}$ plants segregated widely for traits of both parents and were often infertile (table 5). Sharp judgement is needed to identify the resistant plants among the $F_{2}$. They should be selected from among those that have as many fruits as possible, but even so, pollination to the recurrent parents often failed. For this reason, only four $\mathrm{F}_{2}$ populations were grown.

\section{Resistance in hybrids with $\mathrm{L}$. pimpinellifolium}

In general $L$. pimpinellifolium flowers and fruits readily in the hot humid climate of the Mayagüez summers. The fruit loads may be large,

TABLE 3.-Resistance to Altemaria solani in $F_{1}$ lyybrids of L. esculentum $\times$ L. hirsutum f. typicum

\begin{tabular}{|c|c|c|c|c|}
\hline $\begin{array}{l}\text { L. eseulentum } \\
\text { parent }\end{array}$ & $\begin{array}{l}\text { L. hirsutum } \\
\text { parent }\end{array}$ & Yerars tested & $\begin{array}{l}\text { No. of plants } \\
\text { evaluated }\end{array}$ & $\begin{array}{c}\text { Range of } \\
\text { resistance noted }{ }^{1}\end{array}$ \\
\hline Calypso & TA51 (390513) & 1984 & 7 & S-LR \\
\hline Flora-Dade & TA52 (390514) & 1983 & 3 & UR \\
\hline Kewalo & " & 1983,1985 & 11 & UR \\
\hline Calypso & $" t$ & 1983,1984 & 5 & UR \\
\hline Calypso & TA53 (390516) & 1984,1985 & 8 & LR \\
\hline Calypso & TP54 (390658) & 1984 & 8 & LR \\
\hline Flora-Dade & st & 1985 & 2 & LR \\
\hline Flora-Dade & TP57 (390662) & 1984,1985 & 5 & UR \\
\hline
\end{tabular}

${ }^{1} \mathrm{~S}=$ Susceptible; $\overline{L R}=$ light resistance; and $\overline{U R}=$ useful resistance (see note, table 1 ), 
'TABLE 4.-Resistance of BC hybrids of $\mathbf{L}$. esculentum $\times \mathbf{L}$. hirsutum to Alternaria solani

\begin{tabular}{lcccc}
\hline $\begin{array}{c}\text { L. esculentzem } \\
\text { recurrent } \\
\text { parent }\end{array}$ & $\begin{array}{c}\text { L. birsutum } \\
\text { parent }\end{array}$ & Years tested & $\begin{array}{c}\text { No. of plants } \\
\text { evaluated }\end{array}$ & $\begin{array}{c}\text { Highest } \\
\text { resistance noted }\end{array}$ \\
\hline Flora-Dade & TA52 (390514) & 1983,1984 & 22 & UR \\
Kewalo & TA52 (390514) & 1983,1985 & 25 & UR \\
Calypso & TA52 (390514) & 1983,1985 & 24 & UR \\
Kewalo & TA58 (390663) & 1984 & 5 & UR \\
Calypso & TA51 (390513) & 1984 & 15 & S \\
Kewalo & TA53 (390516) & 1985 & 7 & LR \\
Calypso & TA57 (390662) & 1985 & 54 & UR \\
& & $B C_{2}$ & & \\
Flora-Dade & TA52 (390514) & 1984 & 28 & S \\
Calypso & TA57 (390662) & 1984 & 14 & S \\
& & $F_{8}$ of BC & & \\
Flora-Dade & TA52 (390514) & 1984 & 17 & UR \\
Kewalo & TA52 (390514) & 1984 & 12 & LR \\
Calypso & TA52 (390514) & 1984 & 15 & LR \\
Kewalo & TA52 (390514) & 1985 & 10 & UR \\
Calypso & TA52 (390514) & 1985 & 9 & UR \\
\hline
\end{tabular}

${ }^{1} \mathrm{~S}=$ Susceptible; LR = light resistance ${ }_{j}$ and UR = useful resistance (sce note, table 1 ).

TABLE 5.-Resiatance of $F_{2}$ hybrids of L. esculentum $\times$ L. hirsutum to Alternaria solani

\begin{tabular}{llccc}
\hline $\begin{array}{c}\text { L, escutenfam } \\
\text { parent }\end{array}$ & $\begin{array}{c}\text { L hirsutum } \\
\text { parent }\end{array}$ & Years tested & $\begin{array}{c}\text { No. of plants } \\
\text { evaluated }\end{array}$ & $\begin{array}{c}\text { Highest } \\
\text { resistance noted }\end{array}$ \\
\hline Calypso & TA51 (390513) & 1984 & 14 & L,R \\
Flora-Dade & TA51 (390513) & 1984 & 15 & LR \\
Kewalo & TA52 (390514) & 1984 & 11 & UR \\
Calypso & TA57 (390662) & 1985 & 35 & UR \\
\hline
\end{tabular}

' $\mathrm{LR}=$ Light resistance and $\mathrm{UR}=$ useful resistance (see note, table 1 ).

in spite of small fruit size, and whereas some lines are susceptible (table 1) others are resistant (table 2).

Crosses with L. pimpinellifolium are not difficult to make, but during the hot summer the recurrent parents themselves are not very fertile. The hybrids are highly fertile except that some are unfruitful in hot weather. It has been possible to observe early blight resistance in hybrids over several years and several generations.

The resistance of $L$. pimpinellifolium to $A$. solani is usually less than that of $L$, hirsutum. This resistance is seen in the $F_{1}$, suggesting dominance, but in the $\mathrm{F}_{2}$ very few plants are resistant, suggesting that many genes are involved in resistance. Recovery in a single plant of all such genes is difficult (table 6). 
TABLE 6,-Resistance to Alternaria solani in hybrids of L. esculentum $x$ L. pimpinellifolium

\begin{tabular}{ccccc}
\hline $\begin{array}{c}\text { Reeurrent } \\
\begin{array}{c}\text { L. esculentum } \\
\text { parent }\end{array}\end{array}$ & $\begin{array}{c}\text { L.pimpinellifolium } \\
\text { parent }\end{array}$ & Years tested & $\begin{array}{c}\text { No. of plants } \\
\text { evaluated }\end{array}$ & $\begin{array}{c}\text { Highest } \\
\text { resistance noted }\end{array}$ \\
\hline Calypso & TA209 $(395912)$ & $F_{1}$ & & \\
Calypso & TA201 $(395928)$ & 1984 & 10 & LR \\
Calypso & TA220 (390519) & 1984 & 10 & LR \\
Calypso & TA209 (365912) & 1984 & 10 & UR \\
Calypso & TA211 (365928) & 1985 & 5 & LR \\
& & $F_{2}$ & 1 & S \\
Calypso & TA209 (365912) & 1984 & & \\
Calypso & TA211 (365928) & 1984 & 25 & LR \\
Calypso & TA220 (390519) & 1984 & 25 & LR \\
Calypso & TA209 (365912) & 1985 & 23 & UR \\
Calypso & TA220 (390519) & 1985 & 17 & UR \\
\hline
\end{tabular}

${ }^{\circ} \mathrm{S}=$ Susceptible; $\mathrm{LR}=$ light resistance; and UR = useful resistance (see note, table 1 ).

TABLE 7.-Resistance in advanced canning tomato lines from the USA under Mayagiez conditions ${ }^{1}$

\begin{tabular}{clcc}
\hline Our field number & $\begin{array}{c}\text { Barksdale's line } \\
\text { designation }\end{array}$ & $\begin{array}{c}\text { No, of plants } \\
\text { evaluated }\end{array}$ & Resistance noted $^{2}$ \\
\hline 130 & $84 \mathrm{~B} 176$ & 14 & HS-S \\
131 & $84 \mathrm{~B} \mathrm{196}$ & 14 & S-LR \\
132 & $83 \mathrm{~B} 694$ & 5 & S-LR \\
133 & $84 \mathrm{~B} 166$ & 8 & HS-LR \\
134 & $83 \mathrm{~B} 696$ & 5 & S-LR \\
135 & $84 \mathrm{~B} 465-1$ & 4 & S-LR \\
136 & $84 \mathrm{~B} 500-1$ & 10 & S-LR \\
137 & $84 \mathrm{~B} \mathrm{510-3}$ & 14 & S-LR \\
138 & $84 \mathrm{~B} \mathrm{510-4}$ & 14 & LR-UR \\
\hline
\end{tabular}

${ }^{1} 1985$, Lines of Barksdale.

${ }^{2} \mathrm{~S}=$ Susceptible; HS = highly susceptible; $\mathrm{LR}=$ light resistance; and UR = useful resistance (see note, table 1 ).

\section{Resistance of L. eseulentum lines from elsewhere}

Through the goodwill of Barksdale, the most resistant lines in the USA were tested in 1985 . These are eanning tomatoes (table 7). The resistance developed in the United States to $A$. solani appears to be useful there. In 4 years of testing we have not found that resistance adequate for Puerto Rico.

The Barksdale lines appeared to be still segregating for resistance. In most cases, resistance was light and insufficient for use in Puerto Rico. However, in one line, $84 \mathrm{~B} 510-4$, resistance was better and might 
have been sufficient for Puerto Rican conditions. Resistance in this line was almost as good as any we have extracted so far from $L$. hirsutum or L. pimpinellifolium.

\section{DISCUSSION}

There can be no doubt that both Lycopersicon hirsutum and L. pimpinellifolium contain genes affecting susceptibility to early blight, caused by $A$. solani. Apparently both dominant and recessive genes are present. Four years of observation suggest that these genes could give sufficient resistance to this disease to the market tomato, L. esculentum, to permit tomato production during the hot humid weather of the tropical summer. The problem is to transfer these genes into suitable cultivars of the market tomato by normal hybridization and selection techniques.

The diffieulty lies in the problem of identifying and thus selecting the individual genes. This is also complicated by the interaction of such genes with others that affect the morphology of the plant, other disease susceptibilities, and growth patterns; for example, fruit load, a desirable characteristic, increases disease reaction. Whereas it would be ideal to be able to identify each gene by its major and minor effects, this does not appear to be feasible now in the tropies.

Therefore, we suggest the following procedures in searching for resistance to $A$. solani in the tropies.

1. Make all evaluations in comparison to the best resistant lines now available (probably Manalucie and the breeding lines of Barksdale and Stoner).

2. Observe the resistant parents on several seasons, and then select the best for crossing.

3. Cross to established varieties which have characteristics needed in the tropies, especially with ability to set fruit under hot night temperatures.

4. Make the first backcross, producing as many seeds as possible.

5. Self-pollinate the backcross hybrids, select for resistance to hot night temperature and for early blight resistance.

6. Grow the $\mathrm{F}_{2}$ of the $\mathrm{BC}_{1}$ during a time when natural $A$. solani infection is high, or use controlled inoculations under conditions favorable for disease development.

7. Select the best $F_{2}$ segregants for a further backcross, and repeat the cycle.

8. Cross resistant selections from $L$. hirsutum and $L$. pimpinellifolium in hopes of enlarging the pool of resistant genes. This procedure is similar to that recommended by Barksdale (1), and although slow, can lead to the successful transfer of several genes affecting early blight resistance. 


\section{RESUMEN}

Fuentes de resistencia al tizón temprano, Alfernaria solani y su transferencia al fomate, Lycopersicon esculenfum

Líneas de tomate informadas como resistentes al tixón temprano se sembraron y evaluaron bajo infestaciones severamente afectades por el fizón temprano durante la estación fluviosa (verano) de 1982-1985 en Mayagüez, Puerto Rico.

El propósito era identificar las líneas con resistencia útil en Puerto Rico. Esto se definió como poco tizón a pesar de condiciones apropiadas para la enfermedad y sin contral químico. Resistencia útil en el campo se encontró en la minoría de los casos, pero una o más líneas de $L$. esculentum $f$. cerasiforme, $L$. pimpinellifolium, $L$. esculenfum $\times L$. pimpinellifolium y $L$. hirsufum var. typicium mostraron resistencia útil. Las menos afectadas fueron variedades de $\boldsymbol{L}$. hirsufum las cuales también arrojaron los rendimientos más bajos. La mejor producción de tomates se obtuvo con $L$. pimpinellifolium aunque acusaba menos resistencia. Cruces de $L$. esculenfum con $L$. hirsufum con resistencia útil se estudiaron en las generaciones $F_{1}, F_{2}$ y $F_{3}$. La resistencia parecía ser dominante en la $F_{1}$, pero la segregación en la $F_{2}$ sugirió que muchos genes modificadores, dominantes y recesivos, probablemente estuvieron envueltos en la resistencia al tizón temprano. De las líneas de tomate común, 84B 510-4 obtenida de T. Barksdale, era la que más se acercaba en resistencia a las especies silvestres. Generalmente, tomates comunes parecen ser más susceptibles al tizón temprano que las especies silvestres. Para aumentar la agrupación de genes para resistencia, se sugieren seleccionar en la $F_{2}$ y retrocruces progresivos. Las variedades susceptibles se defoliaron un mes después de iniciarse la floración durante el Iluvioso verano, mientras que las variedades con resistencia útil se defoliaron 6 บ 8 semanas después de dicha etapa.

\section{LITERATURE CITED}

1. Barksdale, T. H, 1971. Field evaluation for tomato early blight resistance. Plant Dis. Rep. 55 (9): 807-09.

2. - and A. K. Stoner, 1977. Study of the inheritance of tomato early light resistance. Plant Dis, Rep. 51: 63-5.

3. Bhatia, I. S., D. S. Uppal and K. L. Bahal, 1972. Indian Phytopathol, 25: 231-35.

4. Clark, R. L., J. L. Jarvis, S. W. Braverman, S. M. Dietz, G. Sowell, Jr. and H. F. Winters, 1975. A summary of reports on the resistance of plant introductions to diseases, nematodes, insects, mites, and chemicals. Lycopersicion spp., USDA Agric. Res. Ser.

5. Gardner, R. G., 1984. Use of Lycopersicon hivsutum PI 126445 in breeding eariy blight-resistant tomatoes. HortSci, 19: 208 (Abstr.).

6. Martin, F. W, 1983. Mimeographed annual report on tomatoes. Trop. Agric. Res. Stn., Mayagulez, P. R.

7. Pound, G. S. and M. A. Stahmann, 1951. The production of a toxic material by Altesnaria solani and its relation to the early blight disease of tomato. Phytopathology 41: 1104-114.

8. Reynard, G. B. and C. F. Andrus, 1945. Inheritance of resistance to the collar-rot phase of Altemaria soloni on tomato. Phytopathology 35: 25-36. 
9. Walter, J. M., 1967. Hereditary resistance to disease in tomato. pp. 131-62 In: Ann. Rev. Phytopathol. V, J. G. Horsfall and K. F. Baker (Eds), Annual Reviews, Ine. Palo Alto, Calif.

10. Yang, C. A, 1980. Bacterial and fungal diseases of tomato. pp. 111-23. In: R. Cowell (Ed). Ist International Symposium on Tropical Tomato. Asian Vegetable Research and Development Center, Taiwan.

11. Zhuchenko, A. A., N. N. Balashova and U. K. Andryushchenko, 1975. (The role of the glycoalkaloid-tomatine-in the disease and pest resistances of the tomato.) Original in Russian. Seliskokhozvaistvennaya Biologiya 108: 451-53. 
